\title{
Ghost-Raising in Wales
}

\section{Jonathan Ceredig Davies}

To cite this article: Jonathan Ceredig Davies (1908) Ghost-Raising in Wales, Folklore, 19:3, 327-331, DOI: $10.1080 / 0015587 X .1908 .9719838$

To link to this article: http://dx.doi.org/10.1080/0015587X.1908.9719838

$$
\text { 曲 Published online: } 14 \text { Feb } 2012 .
$$

Submit your article to this journal

Џ Article views: 2

Q View related articles $\sqsubset$ 
nistic to the Christian faith, and cannot bear the sound of holy names."

A number of variants of this tale are given by Clouston in Popular Tales and Fictions, i. p. 352 seq. Crofton Croker's Irish story, alluded to above, is probably the best known. It may be noted that the fairies sing (in Irish) "Monday and Tuesday" again and again to an imperfect air, and the first hunchback earns their gratitude by adding "Wednesday," at the same time completing their air. The air, as well as the Irish words, is given by Croker. The second hunchback spoils the melody by adding "Thursday."

Miss Busk's Italian version is similar, the days being Saturday, Sunday, Monday, and Tuesday. The nearest parallels to the Manx story are the Spanish version and the Breton story given by Keightley. In the Spanish tale the fairies sing "Monday, Tuesday, Wednesday, three"; the first hunchback adds "Thursday, Friday, Saturday, six," while the second spoils it by putting in "Sunday seven." In the Breton story Thursday and Friday are added by the first, and Saturday and Sunday by the second. Thus it appears that only in the Manx and Spanish stories is the addition of Sunday the fatal word which breaks the charm.-ED.].

\section{Ghost-Raising in Wales.}

The possibility of raising spirits, or to cause them to appear, was once believed in in Wales, even in recent times; and Shakespeare, in his Henry the Fourth, Act iii. s. r, makes the Welshman, Glendower, say :

"I can call spirits from the vasty deep."

Wizards and others who practised magical arts were supposed to be able to summon spirits at will.

About three years ago, when I was allowed to search the library of "Harries Cwrt-y-Cadno," a most popular Welsh conjuror who lived in Carmarthenshire about two generations 
ago, I discovered, amongst other curious things, the following "Invocation":

\section{"How to obtain the Familiar of the Genius or Good Spirit and cause him to appear.}

"After the manner prescribed by magicians, the Exorcist must inform himself of the name of his Good Genius, which he may find in the Rules of the Travins and Philermus; as also, what Chonactes and Pentacle, or Larim, belongs to every Genius.

"After this is done, let him compose an earnest prayer unto the said Genius, which he must repeat thrice every morning for seven days before the invocation. . . When the day is come wherein the magician would Invocate his prayer to Genius he must enter into a private closet, having a little table and silk carpet, and two waxen candles lighted; as also a crystal stone shaped triangularly about the quantity of an apple, which stone must be fixed upon a frame in the centre of the table; and then proceeding with great devotion to Invocation, he must thrice repeat the former prayer, concluding the same with Pater Noster, etc., and a Missale de Spiritu Sancto.

"Then he must begin to consecrate the candles, carpet, table and crystal, sprinkling the same with his own blood, and saying: 'I do by the power of the holy names Aglaon, Eloi, Eloi, Sabbathon, Anepturaton, Jah, Agian, Jah, Jehovah, Immanuel, Archon, Archonton, Sadai, Sadai, Jeovaschap, etc., sanctifie and consecrate these holy utensils to the performance of this holy work, in the name of the Father, Son, and Holy Ghost. Amen.'

"Which done, the Exorcist must say the following prayer with his face towards the East, and kneeling with his back to the consecrated table: ' $O$ thou blessed Phanael, my angel guardian, vouchsafe to descend with thy holy influence and presence into this spotless crystal, that I may behold thy glory,' etc.

"This prayer being first repeated towards the East, must be afterwards said towards all the four winds thrice. And next the 70 Psalm, repeated out of a Bible that hath been conse- 
crated in like manner as the rest of the utensils, which ceremonies being seriously performed, the magician must arise from his knees and sit before the crystal bareheaded with the consecrated Bible in his hand and the waxen candle newly lighted waiting patiently and internally for coming and appearance of the Genius. ... .

"Now about a quarter of an hour before the Spirit come, there will appear great variety of apparitions within the glass; as first a beaten road or tract, and travellers, men, and women marching silently along.

"Next there will rivers, wells, mountains, and seas appear, after that a shepherd upon a pleasant hill feeding a goodly flock of sheep, and the sun shining brightly at his going down; and lastly, innumerable flows of birds and beasts, monsters and strange appearance, and which will all vanish at the appearance of the Genius.

"The Genius will be familiar in the stone at the performance of the wizard."

The following story of this Welsh wizard's spirit-summoning was related to me a short time ago by a clergyman who is a native of Carmarthenshire:

\section{The farmer who consulted the conjuror, or the Familiar Spirits and the Lost Cous.}

A farmer who lived in the southern part of Carmarthenshire lost three cows. Having searched in vain for them everywhere, he at last went to Cwrt-y-Cadno, though he had a very long journey to go. When he arrived there and consulted Dr. Harries, the worthy wizard told him that he could not give him any information concerning his lost cows till next day, as he wanted time to consult his magic books. The farmer was a little disappointed, as he wanted to go home that evening; but under the circumstances there was nothing to be done but try and get a bed for the night at some farm in the neighbourhood.

So he left the wizard for the night with the intention of returning to him again in the morning, when he hoped to hear something of his lost cows. 
But after going out of the house, he noticed a barn close by, which he entered, and found in a corner a heap of straw, where he thought he could lie down and sleep comfortably till next morning.

This he did unknown to the wizard, who took for granted that the farmer had gone to stay for the night at some house in the neighbourhood.

He slept comfortably in the barn for a while; but about one o'clock in the morning he was awakened by the sound of the wizard's footsteps entering the place at that untimely hour with a lantern in his hand.

The disturbed farmer could not imagine what he wanted in the barn at this time of the night, and he was afraid of being discovered.

Presently, however, he noticed the conjuror drawing a circle around himself in the middle of the room: that is the wellknown wizard's circle.

Then he stood right in the middle of this circle, and having opened a book, he summoned seven demons or familiar spirits to appear, and in an instant they came one after another and stood outside the circle.

Then he addressed or called out to the first spirit something as follows :

"Tell me where are the farmer's lost cows?"

But the demon answered not.

He repeated the question two or three times, but the Familiar was quite dumb. At last, however, it shouted out, "A pig in the straw," but this was no reply to the wizard's question.

Having failed with the first spirit, the wizard addressed the second one, and then the third, and so on till he had given the question to each one of the familiars except one, without any result. The spirits seemed very stupid on this occasion, and would not give the information required. Fortunately, however, when the question was given to the seventh and last of the demons, it shouted out, "The farmer's cows will be on Carmarthen bridge, at twelve o'clock to-morrow."

Then the wizard left the barn and went to bed well pleased. 
The farmer, who was hiding in the straw, heard everything, and made up his mind to travel to Carmarthen at once, so as to be there in time to find his cows on the bridge.

So off he went to Carmarthen, and reached the bridge just at twelve o'clock, and to his great joy the cows were there!

Then he drove them home, but when he had gone about half-a-mile from the bridge, the cows fell down as if half dead on the roadside, and in vain did he try to get them to move forward any further. So he had to go all the way to Cwrt-yCadno again, so as to consult what to do. When he arrived there "Serve thee right," said the wizard to him, "I have cast a spell on thy cattle for running away secretly last night from the barn without paying me for the information obtained from the spirits."

Then the farmer gave the wizard a certain sum of money and returned to his three cows which he had left on the road half-a-mile from Carmarthen bridge, and to his great joy the cows went home without any further trouble.

The conjuror $I$ have mentioned was both a medical man and a wizard, and there is a tale current in Carmarthenshire that the bearers who carried his body to the churchyard on the day of his burial, when nearing the church, felt the weight of the bier with the body get very light in weight, and that the reason was that the Evil Spirit then took possession of his body, having previously taken possession of his soul at the time of his death.

I also found a similar tale about a conjuror who was buried thirty-five years ago at Llanafan Churchyard, in Cardiganshire. $\mathrm{My}$ informant was present at the funeral.

Jonathan Ceredig Davies. 